\title{
Beneficial Effects of L-Carnitine Supplementation during IVM of Canine Oocytes on Their Nuclear Maturation and Development In Vitro
}

\author{
Adel R. Moawad ${ }^{1, *}$, Ali Salama ${ }^{1}$, Magdy R. Badr ${ }^{2}$ and Mohamed Fathi ${ }^{1}$ \\ 1 Department of Theriogenology, Faculty of Veterinary Medicine, Cairo University, Giza 12211, Egypt; \\ ash_andro@yahoo.com (A.S.); mido2022@yahoo.com (M.F.) \\ 2 Department of AI and ET, Animal Reproduction Research Institute, Agriculture Research Centre, \\ Giza 12556, Egypt; magdybadr69@yahoo.com \\ * Correspondence: adelreda902@hotmail.com
}

check for updates

Citation: Moawad, A.R.; Salama, A.; Badr, M.R.; Fathi, M. Beneficial Effects of L-Carnitine Supplementation during IVM of Canine Oocytes on Their Nuclear Maturation and Development In Vitro. Animals 2021, 11, 581. https://doi.org/10.3390/ ani11020581

Academic Editors: Monica De Los Reyes

Received: 3 January 2021

Accepted: 15 February 2021

Published: 23 February 2021

Publisher's Note: MDPI stays neutral with regard to jurisdictional claims in published maps and institutional affiliations.

Copyright: (c) 2021 by the authors. Licensee MDPI, Basel, Switzerland. This article is an open access article distributed under the terms and conditions of the Creative Commons Attribution (CC BY) license (https:// creativecommons.org/licenses/by/ $4.0 /)$.
Simple Summary: In vitro production of canine embryos is a technique that can be used as a model to conserve endangered species and to establish efficient breeding systems for domestic dogs. However, compared with other species, the success rates of in vitro embryo production (IVEP) in dogs are low. L-Carnitine (LC) is a small water-soluble molecule; it plays an essential role in fatty acid metabolism and acts as a potent antioxidant. Various studies have reported the beneficial impacts of LC on IVEP in many mammalian species other than dogs. Therefore, these experiments investigated the effects of LC supplementation during in vitro maturation (IVM) on canine oocytes maturation, fertilization, and development in vitro. We show that the supplementation of IVM media with LC has positive impacts on oocyte maturation, fertilization, and preimplantation embryo development rates. We also demonstrate that $0.6 \mathrm{mg} / \mathrm{mL} \mathrm{LC}$ is the most beneficial concentration to be used. It resulted in significantly higher maturation, fertilization, and embryo developmental rates than the control and other LC concentrations. These outcomes are essential for refining the IVM conditions that can advance the efficiency of assisted reproductive technologies (ARTs) in dogs.

Abstract: This study aimed to investigate the effect of L-Carnitine (LC) supplementation during in vitro maturation (IVM) of canine oocytes on nuclear maturation, fertilization status, and preimplantation development. Cumulus-oocyte complexes (COCs) collected from the ovaries of ovariohysterectomized female dogs were matured in vitro for $72 \mathrm{~h}$ in a TCM-199 medium supplemented with $(0.1,0.3,0.6,1.0$, or $2.0 \mathrm{mg} / \mathrm{mL})$ or without $(0.0 \mathrm{mg} / \mathrm{mL}) \mathrm{LC}$. Matured oocytes were fertilized in vitro with frozen-thawed spermatozoa, and zygotes were cultured in a SOF medium for 7 days. IVM rates were higher $(p \leq 0.05)$ in 0.3 and $0.6 \mathrm{mg} / \mathrm{mL}$ LC supplemented groups than in the control $(0.0 \mathrm{mg} / \mathrm{mL} \mathrm{LC})$ and other LC groups. Fertilization (18 h postinsemination (pi)) and cleavage (2-16-cell stage at day 3 pi) rates were higher $(p \leq 0.05)$ in the $0.6 \mathrm{mg} / \mathrm{mL}$ LC group than in the control and $0.1,1.0$, and $2 \mathrm{mg} / \mathrm{mL}$ LC supplemented groups. Interestingly, $4.5 \%$ of fertilized oocytes developed to morula (day $5 \mathrm{pi}$ ) in the $0.6 \mathrm{mg} / \mathrm{mL}$ LC group, which was higher $(p \leq 0.05)$ than those developed in the $0.3 \mathrm{mg} / \mathrm{mL}$ group (1.0\%). No cleaved embryos developed to morula in other groups. In conclusion, LC supplementation at $0.6 \mathrm{mg} / \mathrm{mL}$ during IVM of canine oocytes improved their maturation, fertilization, and preimplantation embryo development rates following IVF and in vitro culture (IVC).

Keywords: oocyte; dog; IVM/IVF; L-Carnitine; embryo

\section{Introduction}

Assisted reproductive technologies (ARTs) are required in dog breeding programs to enhance domestic dog reproduction and serve as a model for the conservation of wild and endangered canid species. However, the development of ARTs, for example, in vitro 
maturation of oocytes (IVM), in vitro fertilization (IVF), and embryo culture, has lagged in dogs compared to other domestic species [1]. Failure to develop ARTs in canids results from peculiar species-specific reproductive characteristics of dogs [1]. Dogs are a nonseasonal and monoestrous species, and they ovulate only once or twice a year at an interval of 5-12 months [2]. Canid oocytes also ovulate at an immature stage compared with other mammalian species (pre-germinal vesicle breakdown) and require $48-72 \mathrm{~h}$ in the oviduct postovulation to complete nuclear maturation [2]. The canine oocyte's maturation rate is low compared with other domestic species, and only up to $20-40 \%$ reach the metaphase II (MII) stage [3,4]. Various factors have been reported that impact the meiotic maturation and in vitro development of canid oocytes, including donor age, stage of the reproductive cycle, size of ovarian follicles, culture media, and culture duration [5,6]. It has been reported that the low IVM rates in dogs could be because of inadequate culture conditions that hinder oocytes' ability to resume meiosis [7]. Low IVM rates in dogs are also associated with defects in fertilization and embryo development rates [3]. For example, very few morulae and blastocysts developed following IVF of in vitro matured dog oocytes [8-10], yet no puppies were born from these attempts. Even when in vivo matured oocytes were used, the outcomes were low, and only 7 puppies were born out of 19 transferred embryos [11]. It has recently been reported that IVF of in vivo matured oocytes begets in $66.67 \%$ of two-cell embryo development (18 embryos/27 oocytes) [12]. However, injection of CRISPR-Cas9 into in vivo matured oocytes before IVF (pre-IVF) or in one-cell zygotes after IVF (post-IVF) resulted in lower cleavage rates ( $43.1 \%$ and $38.8 \%$, respectively) [12]. Two healthy puppies were born following a transfer of 15 (pre-IVF) and 13 (post-IVF) embryos [12]. However, none of the control embryos produced live births [12]. Previous studies speculated that IVM of dog oocytes using conventional media and culture conditions is challenging, mainly due to the high intracellular lipids, namely lipid yolk, within the oocytes [6,13]. Analysis of total lipids extracted from canine oocytes has revealed that intracellular lipids are composed of saturated fatty acids, triglycerides, cholesterol, phospholipids, and glycolipids [6,14]. Furthermore, dogs differ from other domestic species in that the oocyte metabolically consumes a high level of glucose via glycolysis [15]. Additionally, the oocyte's developmental ability to achieve nuclear maturation is tightly associated with the metabolism of glucose and glutamine [6,15]. Despite multiple publications, standard systems for in vitro production (IVP) of canine embryos have not yet been developed, and new approaches are needed [16].

L-Carnitine (LC) is a small water-soluble molecule present in most tissues and body fluids. It participates in the mitochondria by beta-oxidation [17]. It also has an antioxidant activity that protects the cells against oxidative stress and DNA damage $[18,19]$. Positive effects of LC on IVEP have been previously reported in many mammalian species. In pigs, LC improved oocyte maturation and embryo development rates, which were linked with an enhancement in mitochondrial activity and reduced intracellular lipid contents and $\mathrm{H}_{2} \mathrm{O}_{2}$ levels [20,21]. In mice, supplementation of the IVM medium with LC improved spindle configuration and chromosome alignment in metaphase II (MII) oocytes, and it enhanced embryonic development through a decrease in apoptosis [22,23]. In camels, LC improved nuclear maturation, fertilization, and blastocyst rates after IVM/IVF and embryo culture [24]. In cattle, LC promoted relocation of active mitochondria to the inner oocyte membrane and subsequently enhanced embryonic development [25]. However, there has been no analysis of the importance of LC concerning canine oocytes' metabolism and development. The present study aimed to investigate the effect of LC supplementation during IVM of canine oocytes on their nuclear maturation, fertilization status, and preimplantation development following IVF and embryo culture.

\section{Materials and Methods}

All chemicals and reagents were purchased from Sigma-Aldrich (St. Louis, MO, USA) unless stated otherwise. 


\subsection{Ovary Collection and Recovery of Cumulus-Oocyte Complexes (COCs)}

Ovaries were obtained from different breeds of healthy domestic bitches at random stages of the estrous cycle ( $n=54,1$ to 6 years old) via routine ovariohysterectomy in the local Egyptian Society for Mercy to Animals (ESMA) under the supervision and approval of the shelter's owners. Ovaries were transported to the laboratory within $1-2 \mathrm{~h}$ in a thermos flask containing sterile phosphate-buffered saline at $37^{\circ} \mathrm{C}$. After transportation, the fat and ligaments were trimmed off carefully and discarded. COCs were released by repeatedly slicing the ovarian cortex with a surgical scalpel blade at room temperature. COCs were then placed in 35-mm Petri dishes containing HEPES-buffered TCM-199 (H-TCM 199) and examined under a stereomicroscope. After three washes in the same medium, COCs with homogeneous dark cytoplasm and three or more layers of compact cumulus cells were chosen for IVM [1,4].

\subsection{IVM and the Evaluation of Nuclear Maturation}

For IVM, groups of 5 to 10 selected COCs were cultured in vitro in $100-\mu \mathrm{L}$ droplets of the maturation medium, namely TCM-199 with Earle's salts, supplemented with $5 \mu \mathrm{g} / \mathrm{mL}$ $\mathrm{oFSH}, 5 \mu \mathrm{g} / \mathrm{mL} \mathrm{oLH}, 10 \% \mathrm{FCS}, 50 \mu \mathrm{g} / \mathrm{mL}$ sodium pyruvate, and $50 \mu \mathrm{g} / \mathrm{mL}$ gentamycin for $72 \mathrm{~h}$ at $39{ }^{\circ} \mathrm{C}$ in $5 \% \mathrm{CO}_{2}$ in the air (control group) $[4,26]$. The IVM medium was covered under mineral oil and pre-equilibrated in the same conditions for at least $4 \mathrm{~h}$ before the start of IVM. For LC-treated groups, COCs were matured under the same conditions in an IVM medium supplemented with $0.1,0.3,0.6,1.0$, or $2.0 \mathrm{mg} / \mathrm{mL} \mathrm{LC}$. The LC doses were selected based on previous studies in other species [22,24]. Nuclear maturation was assessed in denuded oocytes (cumulus cells were removed by gentle pipetting in a hyaluronidase-containing medium) using $1 \%$ orcein staining according to the method previously described [4]. Stained oocytes were examined under a phasecontrast microscope. Based on the chromatin configuration, oocytes with MII plates were considered mature.

\subsection{IVF and Evaluation of Fertilization Status}

For IVF, four frozen semen straws obtained from two mature male dogs were thawed in a water bath at $37^{\circ} \mathrm{C}$ for $30 \mathrm{~s}$ [4]. Thawed semen samples were pooled and resuspended in a $2 \mathrm{~mL}$ sperm-TALP medium supplemented with $5 \mathrm{mM}$ caffeine and then centrifuged at $500 \times g$ for $5 \mathrm{~min}$. Following centrifugation, the supernatant was discarded, and the pellet was resuspended in $1 \mathrm{~mL}$ sperm-TALP. Sperm suspension was kept for $30 \mathrm{~min}$ at $39^{\circ} \mathrm{C}$ in $5 \% \mathrm{CO}_{2}$ in the air for the swim-up. Groups of 10 matured COCs were inseminated with motile spermatozoa at $2 \times 10^{6}$ sperm cells $/ \mathrm{mL}$ in $100 \mu \mathrm{L}$ of fertilization-TALP medium supplemented with $6 \mathrm{mg} / \mathrm{mL}$ BSA, $50 \mu \mathrm{g} / \mathrm{mL}$ gentamycin, and $5 \mathrm{mM}$ caffeine [4]. Gametes were coincubated together for $18 \mathrm{~h}$ at $39{ }^{\circ} \mathrm{C}$ in $5 \% \mathrm{CO}_{2}$ in the air. Eighteen hours postinsemination (pi), the signs of fertilization were determined by staining the denuded oocytes with $1 \%$ orcein staining. Stained oocytes were examined under a phase-contrast microscope. They were categorized as fertilized when their ooplasm contained a swollen sperm head or a male and female pronuclei [4].

\subsection{In Vitro Culture and Embryo Evaluation}

After $18 \mathrm{~h}$ pi, cumulus cells and attached spermatozoa were removed from inseminated oocytes by gentle pipetting in a hyaluronidase-containing medium. Groups of five presumptive zygotes were then cultured in $50-\mu \mathrm{L}$ drops of an embryo culture medium (synthetic oviductal fluid; SOF supplemented with $1 \mathrm{mg} / \mathrm{mL} \mathrm{BSA}$ ) under mineral oil at $39{ }^{\circ} \mathrm{C}$ in a humidified atmosphere of $5 \% \mathrm{CO}_{2}, 5 \% \mathrm{O}_{2}$, and $90 \% \mathrm{~N}_{2}$ until day 7 (day $0=$ day of insemination). The culture medium was changed every $48 \mathrm{~h}$ [27]. Preimplantation embryo development was evaluated under a stereomicroscope, and the proportions of cleaved embryos (2-16 cells), morula, and blastocyst development were assessed on days 3 , 5 , and 7 pi, respectively [4]. 


\subsection{Statistical Analysis}

Three replicates were applied for each experimental group. Data were presented as percentages and analyzed by the chi-square test. Statistical analysis was conducted by GraphPad Prism 5 software. The results were considered to be statistically significant at $p \leq 0.05$.

\section{Results}

\subsection{Effects of LC Supplementation on Nuclear Maturation Rates}

As shown in Table 1, the proportions of mature oocytes in 0.3 and 0.6 and $\mathrm{mg} / \mathrm{mL} \mathrm{LC}$ supplemented groups were higher $(p \leq 0.05)$ than in the control $(0.0 \mathrm{mg} / \mathrm{mL} \mathrm{LC})$ and other experimental groups.

Table 1. Effects of L-Carnitine supplementation during in vitro maturation (IVM) on nuclear maturation rates of canine oocytes $(n=3)$.

\begin{tabular}{ccc}
\hline L-Carnitine $(\mathbf{m g} / \mathbf{m L})$ & Number of Examined Oocytes & Maturation Rate, $\boldsymbol{n}(\%)$ \\
\hline 0 & 197 & $46(23.4)^{\mathrm{a}}$ \\
0.1 & 216 & $54(25.0)^{\mathrm{a}}$ \\
0.3 & 209 & $74(35.4)^{\mathrm{b}}$ \\
0.6 & 227 & $94(41.4)^{\mathrm{b}}$ \\
1 & 206 & $49(23.7)^{\mathrm{a}}$ \\
2 & 203 & $41(20.1)^{\mathrm{a}}$ \\
\hline
\end{tabular}

Values with different superscripts $\left({ }^{\mathrm{a}, \mathrm{b}}\right)$ in the same column are significantly different $(p \leq 0.05)$.

\subsection{Effects of LC Supplementation on Fertilization Events}

As shown in Table 2, the highest fertilization rate was achieved in the $0.6 \mathrm{mg} / \mathrm{mL} \mathrm{LC}$ supplemented group $(25.9 \%)$. This value was higher $(p \leq 0.05)$ than in the control group $(0.0 \mathrm{mg} / \mathrm{mL} \mathrm{LC})$ and $0.1,1.0$, and $2.0 \mathrm{mg} / \mathrm{mL} \mathrm{LC}$ supplemented groups (values ranged from $12.2 \%$ to $14.6 \%$ ). No significant differences were observed between 0.6 and $0.3 \mathrm{mg} / \mathrm{mL} \mathrm{LC}$ groups. Supplementation of the IVM medium with $0.3 \mathrm{mg} / \mathrm{mL}$ LC significantly increased $(p \leq 0.05)$ fertilization rates in comparison to those of the group supplemented with $2.0 \mathrm{mg} / \mathrm{mL}(21.4 \%$ vs. $12.2 \%)$.

Table 2. Effects of L-Carnitine supplementation during IVM on fertilization rates of canine oocytes following in vitro fertilization (IVF) $(n=3)$.

\begin{tabular}{ccc}
\hline L-Carnitine $\mathbf{( m g / m L )}$ & Number of Examined Oocytes & Fertilization Rate, $\boldsymbol{n}(\mathbf{\%})$ \\
\hline 0 & 171 & $24(14.0)^{\mathrm{ac}}$ \\
0.1 & 192 & $28(14.6)^{\mathrm{ac}}$ \\
0.3 & 192 & $41(21.4)^{\mathrm{ab}}$ \\
0.6 & 205 & $53(25.9)^{\mathrm{b}}$ \\
1 & 195 & $28(14.4)^{\mathrm{ac}}$ \\
2 & 181 & $22(12.2)^{\mathrm{c}}$ \\
\hline
\end{tabular}

Values with different superscripts $\left({ }^{\mathrm{a}, \mathrm{b}, \mathrm{c}}\right)$ in the same column are significantly different $(p \leq 0.05)$.

\subsection{Effects of LC Supplementation on Preimplantation Embryo Development}

Supplementation of the IVM medium with $0.6 \mathrm{mg} / \mathrm{mL}$ LC significantly increased $(p \leq 0.05)$ the rate of 2-16-cell embryo development on day 3 pi compared to the control group and the $0.1,1.0$, and $2.0 \mathrm{mg} / \mathrm{mL}$ LC supplemented groups. No significant differences were observed in the 2-16-cell embryo development percentage between 0.6 and $0.3 \mathrm{mg} / \mathrm{mL}$ LC groups (Table 3). Interestingly, $4.5 \%$ of IVM/IVF oocytes developed to morula (day $5 \mathrm{pi}$ ) in a $0.6 \mathrm{mg} / \mathrm{mL}$ LC supplemented group. This value was higher $(p \leq 0.05)$ than that produced in the $0.3 \mathrm{mg} / \mathrm{mL}$ group $(1.0 \%)$. A similar trend was also observed when we calculated the percentage of morula development based on the number of cleaved embryos 
(the values were $27.3 \%$ vs. $7.7 \%$ in 0.6 and $0.3 \mathrm{mg} / \mathrm{mL}$ LC, respectively). No embryos developed beyond the 2-16-cell stage in the rest of the groups (Table 3 ).

Table 3. Effects of L-Carnitine supplementation during IVM on preimplantation embryo development of canine oocytes following IVF and IVC $(n=3)$.

\begin{tabular}{|c|c|c|c|c|c|}
\hline $\begin{array}{l}\text { L-Carnitine } \\
(\mathrm{mg} / \mathrm{mL})\end{array}$ & $\begin{array}{l}\text { Number of } \\
\text { Oocytes }\end{array}$ & $\begin{array}{c}\text { 2-16-Cell Stage } \\
n(\%)\end{array}$ & $\begin{array}{c}\text { Morula/Oocytes, } \\
n(\%)\end{array}$ & $\begin{array}{l}\text { Total Number of Cleaved } \\
\text { Embryos/Oocyte, } n(\%)\end{array}$ & $\begin{array}{l}\text { Morula/Cleaved } \\
\text { Embryos (\%) }\end{array}$ \\
\hline 0 & 171 & $11(6.4)^{\mathrm{a}}$ & $0(0.0)^{\mathrm{a}}$ & $11(6.4)^{a}$ & $0^{a}$ \\
\hline 0.1 & 196 & $15(7.7)^{a b}$ & $0(0.0)^{\mathrm{a}}$ & $15(7.7)^{a}$ & $0^{\mathrm{a}}$ \\
\hline 0.3 & 195 & $26(13.3) b c$ & $2(1.0)^{a}$ & $28(14.4)^{b}$ & $7.7^{\mathrm{a}}$ \\
\hline 0.6 & 202 & $33(16.3)^{c}$ & $9(4.5)^{b}$ & $42(20.8)^{b}$ & $27.3^{b}$ \\
\hline 1 & 184 & $14(7.6)^{a b}$ & $0(0.0)^{a}$ & $14(7.6)^{a}$ & $0^{\mathrm{a}}$ \\
\hline 2 & 187 & $13(6.9)^{a}$ & $0(0.0)^{\mathrm{a}}$ & $13(6.9)^{\mathrm{a}}$ & $0^{\mathrm{a}}$ \\
\hline
\end{tabular}

Values with different superscripts $(\mathrm{a}, \mathrm{b}, \mathrm{c})$ in the same column are significantly different $(p \leq 0.05)$.

\section{Discussion}

In vitro production of canine embryos is a technique that can be used as a model to conserve endangered species and to establish efficient breeding systems for domestic dogs. However, compared with other species, the success rates of IVM/IVF and in vitro embryo development are low in canids. Therefore, the present study aimed to improve the efficiency of in vitro maturation and canine oocytes' development. L-Carnitine acts as an essential cofactor for beta-oxidation; it regulates ATP production from lipids and is a potent antioxidant [28]. We demonstrated that LC supplementation during IVM improved maturation, fertilization, and the development of canine oocytes. We also showed that $0.6 \mathrm{mg} / \mathrm{mL} \mathrm{LC}$ is the most beneficial concentration to be used. It resulted in higher maturation and embryo developmental rates than the control and other LC concentrations.

The decisive role of LC during IVM and embryo culture has been previously reported in many species, including mice [18,22,23,29,30], pigs [20,21,31], cattle [32], and sheep [33,34]. The beneficial effect of LC is likely attributed to its antioxidant capacity and its ability to increase ATP production from intracellular lipid stores $[22,23,28-30]$. The antioxidant effects of L-Carnitine have been confirmed in vitro in somatic cells $[35,36]$ and oocytes [37]. During IVM, oocytes may experience oxidative damage resulting in mitochondria and DNA perturbations and subsequent impairment in fertilization and embryonic development $[22,23,38,39]$. Canine oocytes require up to $72 \mathrm{~h}$ IVM duration to achieve a high nuclear maturation rate [4,9]. During this long culture period, oocytes may experience a damaging effect on the endogenous antioxidant systems, resulting in ROS accumulation that is detrimental to oocytes' developmental competence $[5,6,15]$. Besides, dog oocytes contain many intracellular lipids and are likely to be susceptible to oxidative stress [6]. Therefore, we can speculate from the current study that supplementation of LC at 0.3 and $0.6 \mathrm{mg} / \mathrm{mL}$ during IVM is crucial in protecting dog oocytes against oxidative stress. Several studies have demonstrated the link between the inclusion of L-Carnitine during IVM and the reduction in intracellular ROS and the increase in the antioxidant enzymes within the oocyte of many species, including mice [37], cattle [40], pigs [21,31], and sheep [34]. The nuclear maturation rates reported here in 0.3 and $0.6 \mathrm{mg} / \mathrm{mL}$ LC supplemented groups ( $35.4 \%$ to $41.4 \%$ ) were higher than those reported previously for dog oocytes cultured in vitro for $48 \mathrm{~h}(11.9 \%$ to $18.6 \%$ [27]; $2.2 \%$ to $13.3 \%$ [41]; $8.4 \%$ to $14.7 \%$ [7]; $25.6 \%$ [9]; $27.3 \%$ [42]; and $11.7 \%$ to $17.7 \%$ for oocytes collected from small $(<1 \mathrm{~mm})$ and medium $(1-2 \mathrm{~mm})$ follicles, respectively [15]). However, in the study of Songsasen et al. [15], the collection of oocytes from large $(>2 \mathrm{~mm})$ follicles resulted in comparable maturation rates $(37.7 \%)$ to our 0.3 and $0.6 \mathrm{mg} / \mathrm{mL}$ LC groups. The maturation rate reported in the $0.6 \mathrm{mg} / \mathrm{mL} \mathrm{LC}$ supplemented group was also higher than those demonstrated previously when dog oocytes cultured in vitro for $72 \mathrm{~h}(0.0 \%$ to $6.82 \%$ [1], $25.5 \%$ [4], $2.48 \%$ to $13.23 \%$ [ 43$], 5.56 \%$ to $21.82 \%$ [ 44 ], and $3.8 \%$ [45]). Our findings suggest that LC could positively impact oocyte maturation during a prolonged culture period $[25,46]$. Regarding the effect of LC on fertilization status following IVF, our results show that treatment of oocytes with $0.6 \mathrm{mg} / \mathrm{mL}$ LC during IVM 
improved fertilization rates compared with the control group and other LC concentrations. These findings indicate that LC exerts a beneficial effect not only during IVM but also postfertilization. Higher fertilization rates observed in $0.6 \mathrm{mg} / \mathrm{mL}$ LC treated groups may be due to the higher proportions of matured oocytes noticed in this concentration. The fertilization rate reported here in the $0.6 \mathrm{mg} / \mathrm{mL}$ LC group $(25.8 \%)$ was higher than reported previously in dogs $(15.8 \%, 12 / 76 ; 19 \%, 10 / 52)[4,9]$, assuring the positive impacts of LC on IVF of canine oocytes. Previous studies also reported lower pronucleus formation rates $(1.85 \%$ to $7.69 \%)$ in IVM dog oocytes fertilized by fresh or cooled dog sperm [47]. The beneficial effects of LC supplementation during IVM on IVF rates have also been reported in different domestic species [24].

The beneficial effect of LC exists not only during IVM and IVF but also in the preimplantation embryo development of canine oocytes. Our current findings demonstrate that supplementation of IVM media with $0.6 \mathrm{mg} / \mathrm{mL} \mathrm{LC}$ improved the percentages of cleaved embryos (2-16-cell stage) and morula development at days 3 and 5 pi, respectively (Table 3). In the meantime, we saw only morula development in 0.3 and $0.6 \mathrm{mg} / \mathrm{mL}$ LC groups (1.0\% and $4.5 \%$, respectively). These results indicate that the inclusion of $0.6 \mathrm{mg} / \mathrm{mL} \mathrm{LC}$ during IVM of dog oocytes could support embryo development during IVC. Attempts at IVF of IVM dog oocytes previously resulted in low embryo development rates and no live births $[8,9,12,24,26,27,47]$. For example, only $2 \%$ of inseminated dog IVM oocytes developed to eight-cell embryos at $72 \mathrm{~h}$ post-IVF [42]. Otoi et al. [8] reported that only one canine oocyte developed to the blastocyst stage following IVM/IVF and IVC. Another study revealed that the IVM of dog oocytes for $48 \mathrm{~h}$ resulted in 2.9\% 16-cell embryos and 1\% morula development after IVF and embryo culture; however, none of the oocytes matured for $72 \mathrm{~h}$ developed to these stages [9]. The morula percentage reported in [9] is lower than that reported here in a $0.6 \mathrm{mg} / \mathrm{mL}$ LC supplemented group (4.5\%). It is known that culturing oocytes for a long period increases ROS accumulation and reduces the antioxidant defense mechanism within the oocytes, creating oxidative stress that harmfully impacts oocyte developmental potential $[25,46]$. This notion could explain the low rates of embryo development reported in the oocytes matured for $72 \mathrm{~h}$ in the study of Otoi et al. [9]. High rates of embryo development seen in the current research in the $0.6 \mathrm{mg} / \mathrm{mL}$ LC group indicate that L-Carnitine prevented the harmful consequence of long maturation time. Recent studies showed that LC could prevent oocyte aging and enhance embryos' developmental capacity from aged oocytes by reducing oxidative stress [25,46]. Previous studies reported that $2.76 \%(7 / 253)$ of in vitro matured dog oocytes could develop to 2-5-cell embryos after IVF, from which only two embryos advanced to the 6-8-cell stage within the 7-day IVC period [47]. Another study demonstrated that $1.4 \%$ to $4.1 \%$ of IVM/IVF dog oocytes could develop to the 8-16-cell stage at $96-120 \mathrm{~h}$ pi without further progress beyond this stage [27].

Substantial research shows that the IVM culture media composition affects COC metabolism and metabolic rate, and the developmental competence of the oocytes is affected by their metabolism [48]. Besides, the processes of oocyte growth, maturation, fertilization, and subsequent preimplantation embryo development require the generation of a sufficient amount of ATP [49]. The utilization of carbohydrates, glucose, pyruvate, and lactate for ATP production has been well identified in the COC [48]. However, fatty acid metabolism via beta-oxidation is a potent energy source with an energy production capacity several-fold higher than that of carbohydrates [28]. Production of energy from intracellular stores of the oocyte during IVM is crucial in species with high levels of stored lipids, such as dogs $[6,28]$. Beta-oxidation of fatty acids requires the essential cofactor L-Carnitine to transport activated fatty acids from the cytosol into the mitochondria. The addition of L-Carnitine to in vitro cell line cultures is known to increase beta-oxidation $[28,50]$. The beneficial impacts of L-Carnitine on dog oocyte development reported in the current study could be due to its implications for the energy production of intracellular lipid stores within the oocyte. The link between L-Carnitine and beta-oxidation of fatty acids and the metabolism of canine oocytes warrants further investigation. 


\section{Conclusions}

In summary, L-Carnitine supplementation during IVM of canine oocytes improved their nuclear maturation, fertilization rates, and subsequent preimplantation embryo development following IVF and embryo culture. Among the different concentrations used, $0.6 \mathrm{mg} / \mathrm{mL} \mathrm{LC}$ seems to be the most beneficial one as it produced higher rates of day 5 morula development. These outcomes are crucial for the refinement of IVM conditions that can advance the efficiency of in vitro embryo production in dogs.

Author Contributions: Conceptualization, A.R.M., A.S., M.R.B., and M.F.; methodology, A.R.M., A.S., M.R.B., and M.F.; software, A.R.M.; validation, A.R.M., A.S., M.R.B., and M.F.; formal analysis, A.R.M.; investigation, A.R.M., A.S., M.R.B., and M.F.; resources, A.R.M., A.S., M.R.B., and M.F.; data curation, A.R.M., A.S., M.R.B., and M.F.; writing—original draft preparation, A.R.M.; writing-review and editing, A.R.M.; visualization, A.R.M., A.S., M.R.B., and M.F.; supervision, A.R.M., A.S., M.R.B., and M.F.; project administration, A.R.M., A.S., M.R.B., and M.F.; funding acquisition, A.R.M., A.S., M.R.B., and M.F. All authors have read and agreed to the published version of the manuscript.

Funding: This research received no external funding.

Institutional Review Board Statement: The study was conducted according to the guidelines of the Declaration of Helsinki, and approved by Institutional Animal Care and Use Committee, Cairo University (CU-IACUC), Egypt (protocol code CU-IACUC 07-2018 and date of approval 16 July 2018).

Informed Consent Statement: Not applicable.

Data Availability Statement: All data sets obtained and analyzed during the experiment are available on fair request from the respective author.

Acknowledgments: Faculty of Veterinary Medicine, Cairo University, and the local Egyptian Society for Mercy to Animals (ESMA).

Conflicts of Interest: The authors declare no conflict of interest.

\section{References}

1. Abdel-Ghani, M.A.; Abe, Y.; Asano, T.; Hamano, S.; Suzuki, H. Effect of bovine cumulus-oocyte complexes-conditioned medium on in-vitro maturation of canine oocytes. Reprod. Med. Biol. 2011, 10, 43-49. [CrossRef] [PubMed]

2. Hewitt, D.A.; England, G.C. Synthetic oviductal fluid and oviductal cell coculture for canine oocyte maturation in vitro. Anim. Reprod. Sci. 1999, 55, 63-75. [CrossRef]

3. Farstad, W. Assisted reproductive technology in canid species. Theriogenology 2000, 53, 175-186. [CrossRef]

4. Fathi, M.; Salama, A.; Badr, M.R. Improvement of the developmental competence of canine oocyte using caffeine supplementation during IVM at different maturation time. Zygote 2018, 26, 162-167. [CrossRef] [PubMed]

5. Songsasen, N.; Yu, I.; Leibo, S.P. Nuclear maturation of canine oocytes cultured in protein-free media. Mol. Reprod. Dev. 2002, 62, 407-415. [CrossRef] [PubMed]

6. Songsasen, N.; Wildt, D.E. Oocyte biology and challenges in developing in vitro maturation systems in the domestic dog. Anim. Reprod. Sci. 2007, 98, 2-22. [CrossRef]

7. Willingham-Rocky, L.A.; Hinrichs, K.; Westhusin, M.E.; Kraemer, D.C. Effects of stage of oestrous cycle and progesterone supplementation during culture on maturation of canine oocytes in vitro. Reproduction 2003, 126, 501-508. [CrossRef]

8. Otoi, T.; Murakami, M.; Fujii, M.; Tanaka, M.; Ooka, A.; Une, S.; Suzuki, T. Development of canine oocytes matured and fertilised in vitro. Vet. Rec. 2000, 146, 52-53. [CrossRef] [PubMed]

9. Otoi, T.; Shin, T.; Kraemer, D.C.; Westhusin, M.E. Influence of maturation culture period on the development of canine oocytes after in vitro maturation and fertilization. Reprod. Nutr. Dev. 2004, 44, 631-637. [CrossRef] [PubMed]

10. Hatoya, S.; Sugiyama, Y.; Torii, R.; Wijewardana, V.; Kumagai, D.; Sugiura, K.; Kida, K.; Kawate, N.; Tamada, H.; Sawada, T.; et al. Effect of co-culturing with embryonic fibroblasts on IVM, IVF and IVC of canine oocytes. Theriogenology 2006, 66, 1083-1090. [CrossRef]

11. Nagashima, J.B.; Sylvester, S.R.; Nelson, J.L.; Cheong, S.H.; Mukai, C.; Lambo, C.; Flanders, J.A.; Meyers-Wallen, V.N.; Songsasen, N.; Travis, A.J. Live Births from Domestic Dog (Canis familiaris) Embryos Produced by In Vitro Fertilization. PLoS ONE 2015, 10, e0143930. [CrossRef] [PubMed]

12. Mukai, C.; Nelson, J.L.; Cheong, S.H.; Diel de Amorim, M.; Travis, A.J. Impacts of oocyte/zygote timing for in vitro fertilization and gene editing in the dog. Theriogenology 2020, 150, 347-352. [CrossRef]

13. Kim, M.K.; Fibrianto, Y.H.; Oh, H.J.; Jang, G.; Kim, H.J.; Lee, K.S.; Kang, S.K.; Lee, B.C.; Hwang, W.S. Effects of estradiol-17beta and progesterone supplementation on in vitro nuclear maturation of canine oocytes. Theriogenology 2005, 63, 1342-1353. [CrossRef] 
14. Chastant-Maillard, S.; Viaris de Lesegno, C.; Chebrout, M.; Thoumire, S.; Meylheuc, T.; Fontbonne, A.; Chodkiewicz, M.; Saint-Dizier, M.; Reynaud, K. The canine oocyte: Uncommon features of in vivo and in vitro maturation. Reprod. Fertil. Dev. 2011, 23, 391-402. [CrossRef]

15. Songsasen, N.; Wesselowski, S.; Carpenter, J.W.; Wildt, D.E. The ability to achieve meiotic maturation in the dog oocyte is linked to glycolysis and glutamine oxidation. Mol. Reprod. Dev. 2012, 79, 186-196. [CrossRef] [PubMed]

16. Evecen, M.; Cirit, U.; Demir, K.; Hamzaoglu, A.I.; Bakirer, G.; Pabuccuoglu, S.; Birler, S. Adding hormones sequentially could be an effective approach for IVM of dog oocytes. Theriogenology 2011, 75, 1647-1651. [CrossRef] [PubMed]

17. Melegh, B.; Sumegi, B.; Sherry, A.D. Preferential elimination of pivalate with supplemental carnitine via formation of pivaloylcarnitine in man. Xenobiotica 1993, 23, 1255-1261. [CrossRef]

18. Mansour, G.; Abdelrazik, H.; Sharma, R.K.; Radwan, E.; Falcone, T.; Agarwal, A. L-carnitine supplementation reduces oocyte cytoskeleton damage and embryo apoptosis induced by incubation in peritoneal fluid from patients with endometriosis. Fertil. Steril. 2009, 91, 2079-2086. [CrossRef]

19. Abdelrazik, H.; Sharma, R.; Mahfouz, R.; Agarwal, A. L-carnitine decreases DNA damage and improves the in vitro blastocyst development rate in mouse embryos. Fertil. Steril. 2009, 91, 589-596. [CrossRef]

20. Wu, G.Q.; Jia, B.Y.; Li, J.J.; Fu, X.W.; Zhou, G.B.; Hou, Y.P.; Zhu, S.E. L-carnitine enhances oocyte maturation and development of parthenogenetic embryos in pigs. Theriogenology 2011, 76, 785-793. [CrossRef] [PubMed]

21. You, J.; Lee, J.; Hyun, S.H.; Lee, E. L-carnitine treatment during oocyte maturation improves in vitro development of cloned pig embryos by influencing intracellular glutathione synthesis and embryonic gene expression. Theriogenology 2012, 78, 235-243. [CrossRef] [PubMed]

22. Moawad, A.R.; Tan, S.L.; Xu, B.; Chen, H.Y.; Taketo, T. L-carnitine supplementation during vitrification of mouse oocytes at the germinal vesicle stage improves preimplantation development following maturation and fertilization in vitro. Biol. Reprod. 2013, 88,104 . [CrossRef]

23. Moawad, A.R.; Xu, B.; Tan, S.L.; Taketo, T. 1-carnitine supplementation during vitrification of mouse germinal vesicle stage-oocytes and their subsequent in vitro maturation improves meiotic spindle configuration and mitochondrial distribution in metaphase II oocytes. Hum. Reprod. 2014, 29, 2256-2268. [CrossRef]

24. Fathi, M.; El-Shahat, K.H. L-carnitine enhances oocyte maturation and improves in vitro development of embryos in dromedary camels (Camelus dromedaries). Theriogenology 2017, 104, 18-22. [CrossRef]

25. Jiang, W.J.; Yao, X.R.; Zhao, Y.H.; Gao, Q.S.; Jin, Q.G.; Li, Y.H.; Yan, A.G.; Xu, Y.N. L-carnitine prevents bovine oocyte aging and promotes subsequent embryonic development. J. Reprod. Dev. 2019, 65, 499-506. [CrossRef]

26. De los Reyes, M.; Carrion, R.; Barros, C. In vitro fertilization of in vitro matured canine oocytes using frozen-thawed dog semen. Theriogenology 2006, 66, 1682-1684. [CrossRef]

27. Saikhun, J.; Sriussadaporn, S.; Thongtip, N.; Pinyopummin, A.; Kitiyanant, Y. Nuclear maturation and development of IVM/IVF canine embryos in synthetic oviductal fluid or in co-culture with buffalo rat liver cells. Theriogenology 2008, 69, 1104-1110. [CrossRef]

28. Dunning, K.R.; Robker, R.L. The role of L-carnitine during oocyte in vitro maturation: Essential co-factor? Anim. Reprod. 2017, 14, 469-475. [CrossRef]

29. Dunning, K.R.; Cashman, K.; Russell, D.L.; Thompson, J.G.; Norman, R.J.; Robker, R.L. Beta-oxidation is essential for mouse oocyte developmental competence and early embryo development. Biol. Reprod. 2010, 83, 909-918. [CrossRef]

30. Dunning, K.R.; Robker, R.L. Promoting lipid utilization with 1-carnitine to improve oocyte quality. Anim. Reprod. Sci. 2012, 134, 69-75. [CrossRef]

31. Somfai, T.; Kaneda, M.; Akagi, S.; Watanabe, S.; Haraguchi, S.; Mizutani, E.; Dang-Nguyen, T.Q.; Geshi, M.; Kikuchi, K.; Nagai, T. Enhancement of lipid metabolism with L-carnitine during in vitro maturation improves nuclear maturation and cleavage ability of follicular porcine oocytes. Reprod. Fertil. Dev. 2011, 23, 912-920. [CrossRef]

32. Takahashi, T.; Inaba, Y.; Somfai, T.; Kaneda, M.; Geshi, M.; Nagai, T.; Manabe, N. Supplementation of culture medium with L-carnitine improves development and cryotolerance of bovine embryos produced in vitro. Reprod. Fertil. Dev. 2013, 25, 589-599. [CrossRef] [PubMed]

33. Reader, K.L.; Cox, N.R.; Stanton, J.A.; Juengel, J.L. Effects of acetyl-L-carnitine on lamb oocyte blastocyst rate, ultrastructure, and mitochondrial DNA copy number. Theriogenology 2015, 83, 1484-1492. [CrossRef] [PubMed]

34. Mishra, A.; Reddy, I.J.; Gupta, P.; Mondal, S. Developmental regulation and modulation of apoptotic genes expression in sheep oocytes and embryos cultured in vitro with L-carnitine. Reprod. Domest. Anim. 2016, 51, 1020-1029. [CrossRef]

35. Ribas, G.S.; Manfredini, V.; de Marco, M.G.; Vieira, R.B.; Wayhs, C.Y.; Vanzin, C.S.; Biancini, G.B.; Wajner, M.; Vargas, C.R. Prevention by L-carnitine of DNA damage induced by propionic and L-methylmalonic acids in human peripheral leukocytes in vitro. Mutat. Res. 2010, 702, 123-128. [CrossRef]

36. Silva-Adaya, D.; Perez-De La Cruz, V.; Herrera-Mundo, M.N.; Mendoza-Macedo, K.; Villeda-Hernandez, J.; Binienda, Z.; Ali, S.F.; Santamaria, A. Excitotoxic damage, disrupted energy metabolism, and oxidative stress in the rat brain: Antioxidant and neuroprotective effects of L-carnitine. J. Neurochem. 2008, 105, 677-689. [CrossRef]

37. Zare, Z.; Masteri Farahani, R.; Salehi, M.; Piryaei, A.; Ghaffari Novin, M.; Fadaei Fathabadi, F.; Mohammadi, M.; DehghaniMohammadabadi, M. Effect of L-carnitine supplementation on maturation and early embryo development of immature mouse oocytes selected by brilliant cresyle blue staining. J. Assist. Reprod. Genet. 2015, 32, 635-643. [CrossRef] 
38. Combelles, C.M.; Gupta, S.; Agarwal, A. Could oxidative stress influence the in-vitro maturation of oocytes? Reprod. Biomed. Online 2009, 18, 864-880. [CrossRef]

39. Moawad, A.R.; Tan, S.L.; Taketo, T. Beneficial effects of glutathione supplementation during vitrification of mouse oocytes at the germinal vesicle stage on their preimplantation development following maturation and fertilization in vitro. Cryobiology 2017, 76, 98-103. [CrossRef]

40. Sovernigo, T.C.; Adona, P.R.; Monzani, P.S.; Guemra, S.; Barros, F.; Lopes, F.G.; Leal, C. Effects of supplementation of medium with different antioxidants during in vitro maturation of bovine oocytes on subsequent embryo production. Reprod. Domest. Anim. 2017, 52, 561-569. [CrossRef]

41. Sato, A.; Sarentonglaga, B.; Ogata, K.; Yamaguchi, M.; Hara, A.; Atchalalt, K.; Sugane, N.; Fukumori, R.; Nagao, Y. Effects of insulin-like growth factor-1 on the in vitro maturation of canine oocytes. J. Reprod. Dev. 2018, 64, 83-88. [CrossRef] [PubMed]

42. Yamada, S.; Shimazu, Y.; Kawaji, H.; Nakazawa, M.; Naito, K.; Toyoda, Y. Maturation, fertilization, and development of dog oocytes in vitro. Biol. Reprod. 1992, 46, 853-858. [CrossRef]

43. No, J.; Zhao, M.; Lee, S.; Ock, S.A.; Nam, Y.; Hur, T.Y. Enhanced in vitro maturation of canine oocytes by oviduct epithelial cell co-culture. Theriogenology 2018, 105, 66-74. [CrossRef]

44. Lange-Consiglio, A.; Perrini, C.; Albini, G.; Modina, S.; Lodde, V.; Orsini, E.; Esposti, P.; Cremonesi, F. Oviductal microvesicles and their effect on in vitro maturation of canine oocytes. Reproduction 2017, 154, 167-180. [CrossRef]

45. Salavati, M.; Ghafari, F.; Zhang, T.; Fouladi-Nashta, A.A. Effects of oxygen concentration on in vitro maturation of canine oocytes in a chemically defined serum-free medium. Reproduction 2012, 144, 547-556. [CrossRef]

46. Jiang, W.; Li, Y.; Zhao, Y.; Gao, Q.; Jin, Q.; Yan, C.; Xu, Y. l-carnitine supplementation during in vitro culture regulates oxidative stress in embryos from bovine aged oocytes. Theriogenology 2020, 143, 64-73. [CrossRef]

47. Rodrigues Bde, A.; dos Santos, L.C.; Rodrigues, J.L. Effect of maturation medium on in vitro cleavage of canine oocytes fertilized with fresh and cooled homologous semen. Zygote 2007, 15, 43-53. [CrossRef]

48. Brown, H.M.; Dunning, K.R.; Sutton-McDowall, M.; Gilchrist, R.B.; Thompson, J.G.; Russell, D.L. Failure to launch: Aberrant cumulus gene expression during oocyte in vitro maturation. Reproduction 2017, 153, R109-R120. [CrossRef]

49. Van Blerkom, J.; Davis, P.W.; Lee, J. ATP content of human oocytes and developmental potential and outcome after in-vitro fertilization and embryo transfer. Hum. Reprod. 1995, 10, 415-424. [CrossRef]

50. Huynh, F.K.; Green, M.F.; Koves, T.R.; Hirschey, M.D. Measurement of fatty acid oxidation rates in animal tissues and cell lines. Methods Enzymol. 2014, 542, 391-405. [CrossRef] 